\title{
THE BLUE JAY
}

Published quarterly by the Saskatchewan Natural History Society

Founded in 1942 by Isabel M. Priestly

Authorized as second class mail and for payment of postage in cash

P.O. Department, Ottawa

\section{TABLE OF CONTENTS}

FAR AWAY CRANES, Editorial.

GEOLOGY AND NATURAL HISTORY, Reflections on the late J. B. Mawdsley and F. H. Edmunds.

TOPOGRAPHY AND SURFACE DEPOSITS OF PART OF SASKATCHEWAN BIRDS

in relation to the recession of the Pleistocene ice sheet, the late $F . H$. Edmunds 59

Sandhill Crane studies on Banks Island, Northwest Territories,

Lawrence H. Walkinshaw

Black-headed Grosbeak breeding record for south-central Saskatchewan, Robert D. Symons and Robert W. Nero

A possible sight record of the Black-headed Grosbeak in Manitoba,

Martin McNicholl

Summer record of a Snowy Owl, Garry L. Fletcher ……..................................... 78

An observation of bird mortality on highways, Keith D. Baker ……..................... 79

Some feeding habits of the Ruby-throated Hummingbird, Alvin Binnie ................ 80

Caspian Tern again sighted at Regina, Robert $W$. Nero ……........................... 81

Two Egyptian Geese shot in Saskatchewan, W. Harvey Beck ……....................... 82

Second Poor-will specimen for Saskatchewan, $W$. Harvey Beck ……...................... 82

Bird notes from Uranium City .................................................................... 82

A breeding record of the Starling at Lookout Point, Northwest Territories, Ernie Kuyt

Unusually large brood size of the Saw-whet Owl, Spencer G. Sealy

Unusual nest site of a Horned Lark, Gary Anweiler

Record of a Wood Duck at Ituna, Mrs. Mary F. Brennan

A comparison of two Common Snipe nests, Jack Lane

Seventh annual report (1964) of the Prairie Nest Records Scheme, Robert R. Taylor

\section{MAMMALS}

The Kyle Woolly Mammoth, Saskatchewan Museum of Natural History .......... 88

Albino Red Squirrel collected in Wood Buffalo Park, Thomas J. Wood ............ 90

Lynx along the Cutarm Creek, A. J. Hruska ........................................... 90

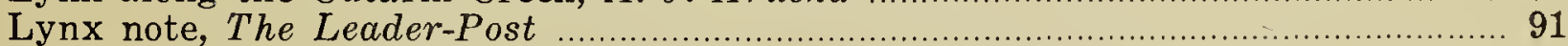

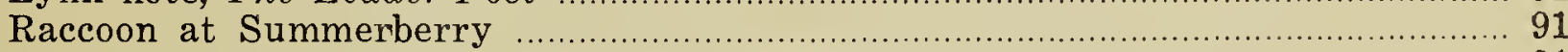

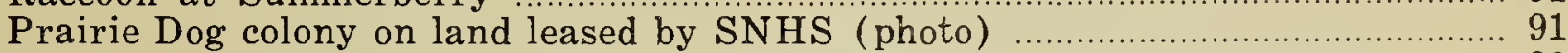

Correction of mammal record, Thomas Heastip ..................................... 92

REPTILES AND AMPHIBIANIS

Horned Toad record, J. David Chandler .................................................. 92

The Boreal Chorus Frog in northern Saskatchewan, W. Harvey Beck .............. 92

INSECTS

Butterfly discoveries of 1964, Ronald Hooper .............................................. 93

PLANTS

Tall Wormseed Mustard, Erysimum hieraciifolium L. in Saskatchewan,

F. H. Montgomery

Large Fringe-cup, photo by the late $D r . W . C . M c C a l l a$

A plant collection from the Cochrane River region of northwestern Manitoba,

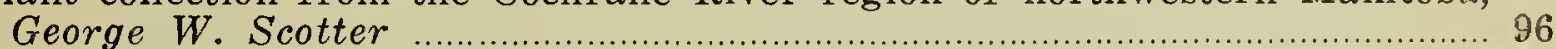

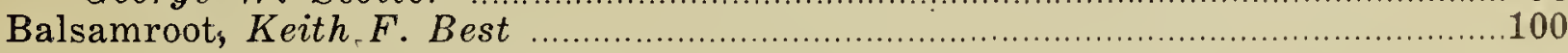

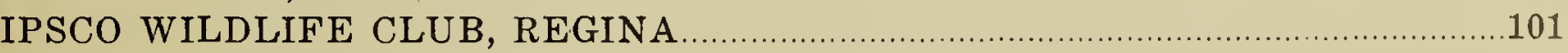

JUNIOR NATURALISTS, edited by Joyce Deutscher............................................102

THE BLUE JAY BOOKSHELF

Weeds of Canada and the northern United States, by F. H. Montgomery, reviewed by Jack $F$. Alex

1

2

Wild plants of the Canadian Prairies, by Archibald C. Budd and Keith F. B reviewed by Jack $F$. Alex

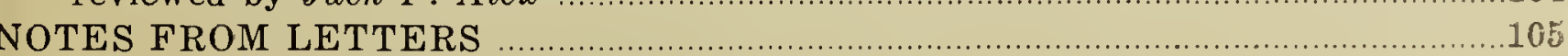

SOCIETY NEW'S

The Nature Conservancy of Canada, George F. Ledingham...........................111

Presentation to George F. Ledingham, Editor........................................112

Any material printed for the first time in the Blue Jay may be reproduced vithout permission. Credit lines will be appreciated. 